Creative Commons User License: CC BY-NC-ND

Abstracted by: EBSCOhost, Electronic Journals Service (EJS), Google Scholar, Journal Seek, Scientific Commons,

Food and Agricultural Organization (FAO), CABI and Scopus

http://eoi.citefactor.org/10.11226/v25i3
Journal of Agricultural Extension

Vol. 25 (3) July, 2021

ISSN(e): 24086851; ISSN(Print); 1119944X

http://journal.aesonnigeria.org

http://www.ajol.info/index.php/jae

Email: editorinchief@aesonnigeria.org

\title{
Comparative Analysis of the Level of Engagement in Palm Oil Processing Among Rural Households in Southeast Nigeria
}

https://dx.doi.org/10.4314/jae.v25i3.3

\author{
Onu, Samson Ejike \\ Department of Rural Sociology and Extension \\ Michael Okpara University of Agriculture Umudike \\ Email: samsononu@gmail.com, Phone: +2348134870488
}

Ekwe, Kenneth C.

Department of Rural Sociology and Extension

Michael Okpara University of Agriculture Umudike

Email:kcekwe@yahoo.com, Phone: +2348063599791

\section{Onuekwusi, Gideon Chinedu}

Department of Rural Sociology and Extension

Michael Okpara University of Agriculture Umudike

Email:onuekwusi.gideon@mouau.edu.ng,

\begin{abstract}
The study provided empirical evidence of rural household's engagement in processing of oil palm produce in South east Nigeria. The study specifically identified the methods of processing oil palm produce, ascertained the level of household's engagement in oil palm processing, identified the constraints to oil palm processing in the study area. Multi-stage random sampling procedure in selecting 540 respondents. Data for the study were collected with the use of structured questionnaire and analyzed with the use of both descriptive (frequency, percentage and mean) and inferential statistics (ANOVA model). The results showed that $58.1 \%$ of the respondents used semi-modern/mechanized in processing of oil palm produce. There was high level of engagement in the processing of oil palm produce (pooled grand mean $=3.67$ ). The result revealed that lack of modern processing equipment (86.5\%), instability of government policy (80.0\%) and high cost of labour (76.7\%) were the major constraints to engagement in oil palm processing. There was a statistically significant difference in the level of engagement of rural households in processing of oil palm produce across the states in South East Nigeria at $5 \%$ level of probability. The study concluded that most of the processors used a combination of both traditional and modern method in the processing of their oil palm produce and were highly engaged in the processing of oil palm produce as a profitable livelihood activity. The study therefore recommended that State and Federal Government should gear up efforts in providing basic infrastructure such as electricity and good, motorable roads in the study area so that the efficiency of processing of oil palm products can be guaranteed.
\end{abstract}

Keywords: Oil palm, engagement, palm oil processing, rural households 
Creative Commons User License: CC BY-NC-ND

Abstracted by: EBSCOhost, Electronic Journals Service (EJS),

Google Scholar, Journal Seek, Scientific Commons,

Food and Agricultural Organization (FAO), $\mathrm{CABI}$ and Scopus
Journal of Agricultural Extension

Vol. 25 (3) July, 2021

ISSN(e): 24086851; ISSN(Print); 1119944X

http://journal.aesonnigeria.org

http://www.ajol.info/index.php/jae

Email: editorinchief@aesonnigeria.org

\section{Introduction}

Oil palm (Elaeis guineensis) is one of the most important economic oil crops in Nigeria. Oil palm is indigenous to the Nigerian coastal plain though it has migrated inland as a staple crop (Alabi, Famakinwa and Akinnawonu ,2020 and Nwalieji and Ojike 2018). The high demand for palm oil is making oil palm cultivation becoming a means of livelihood for many rural families, and indeed the farming culture of millions of people in Nigeria especially Southeast. The oil palm tree is a useful crop that is relevant in all aspects of live with socioeconomic and socio-cultural values.

Foundation for Partnership Initiatives in the Niger Delta (PIND) (2019) reported that up until the 1960s, Nigeria was the world's largest producer of palm oil accounting for $43 \%$ of global palm oil production. Over-reliance on traditional production methods, excessive tapping of palm trees for palm wine and the civil war between 1967-1970, are factors that contributed to Nigeria's inability to meet up with the global rise in demand for palm oil (PIND, 2019). According to a report Statista (2020), in 2020, the production of palm oil in Nigeria was estimated to be 1,015 thousand metric tons. Between 2010 and 2020, the palm oil production in the country increased, registering the highest growth in 2010, when the production grew by 14 percent compared to the previous year. In the last three years (2018-2020), the production remained stable at over one million metric tons. Nigeria is one of the leading five producers of palm oil worldwide.

Processing of oil palm fruit is defined as a process by which palm fruit is processed into palm oil through threshing or stripping, milling and digestion, pressing and clarification. Oil palm fruit processing involves harvesting, threshing or bunch quartering, fruit loosening, boiling, digestion, pressing/oil extraction, clarification and packaging/storage. All these stages are done manually except the digestion or pounding of cooked fruits which is done by a diesel engine powered digester equipment (Osei-Amponsah et al., 2018). Small- scale production involves the use of traditional or semi-mechanized methods for oil extraction from the fresh fruit bunch. Oyeronke and Adedotun (2019), observed two broad methods of palm oil processing, thus the traditional or manual methods normally referred to as "low" technology and the mechanized or modern method of processing basically the same principles as the present industrial method, the difference is the equipment and technology being employed and of course the quality of each method and it is common knowledge that the use of machine enhances productivity. In addition, during processing, outdated equipment is mostly used. This method of oil palm processing is arduous, time consuming and oil yield is usually low. Often, about $25 \%$ - $75 \%$ of potential palm oil is lost during processing while $71.8-90.6 \%$ and $9.0-$ 
Creative Commons User License: CC BY-NC-ND

Abstracted by: EBSCOhost, Electronic Journals Service (EJS),

Google Scholar, Journal Seek, Scientific Commons,

Food and Agricultural Organization (FAO), $\mathrm{CABI}$ and Scopus
Journal of Agricultural Extension

Vol. 25 (3) July, 2021

ISSN(e): 24086851; ISSN(Print); 1119944X

http://journal.aesonnigeria.org

http://www.ajol.info/index.php/jae

Email: editorinchief@aesonnigeria.org

$28.0 \%$ palm oil end up as waste under smallholder palm oil processing in Nigeria depending on the variety of the oil palm (Eric and Ikheloha, 2017).

Oyeronke and Adedotun (2019) stated that palm fruit can be processed by using the traditional method or more sophisticated method. The industrial method is processed: After harvesting the fruits in the groves or plantation, the fruit bunches are moved to the mill. Here the fresh fruit bunches are weighted and then quartered before they are transferred to the sterilization unit where they are cooked. After sterilization, the next step is stripping and threshing to separate the fruit from the husks. The husks are then discarded and later used as fuel for firing furnaces that power the sterilizer. The separated fruits are then transferred to the digester where the cooked fruits are mashed into a pulp. The mash is transferred to the presser from where the palm oil will be squeezed out and transferred into a clarifier for sedimentation. While the traditional method are employed by peasant women and small processors using mortars. Palm oil has always been processed by using traditional primitive rural technique of cooking the palm fruits in a pot and pounding the cooked fruits in a wooden mortar. The mash is then squeezed either by hand or any other method which will squeeze the palm oil out of the mash. Nwalieji and Ojike (2018) reiterated that majority of palm oil processors adopt traditional technique of processing.

Studies by Nwalieji and Ojike (2018), Alabi et al (2020) and Onu, Ekwe and Nwachukwu (2021) revealed that oil palm fruit processing is a major economic activity of the people of Southern Nigeria and is mostly carried out by rural dwellers particularly women under manual and subsistence methods. Usually, local producers will take their processed oil and kernel to the periodic or daily markets, or display same by the road side or village square where prospective buyers will come for purchase. The major constraints of palm oil processing according to Alabi et al. (2020) are the supply of inputs, the inefficiency of processing methods, the low quality of the output, the lack of infrastructure and inefficient distribution. With regards to production, the traditional method is dominant, so yields remain low. For rural poor households, this method is very tedious and laborious compared to mechanical methods and requires a substantial proportion of labour force. More so, it is observed that traditional methods of extracting palm produce are inefficient and tedious.

Obviously, oil palm fruit processing activities are dominated by smallholders located in the rural communities of Nigeria. These smallholders account for the greater percentage of palm produce output in the area but their output cannot even satisfy local demands both quantitatively and qualitatively. The small-scale farmers who constitute the bulk of oil palm producers in the study area seemed not to be 
Creative Commons User License: CC BY-NC-ND

Abstracted by: EBSCOhost, Electronic Journals Service (EJS),

Google Scholar, Journal Seek, Scientific Commons,

Food and Agricultural Organization (FAO), CABI and Scopus
Journal of Agricultural Extension

Vol. 25 (3) July, 2021

ISSN(e): 24086851; ISSN(Print); 1119944X

http://journal.aesonnigeria.org

http://www.ajol.info/index.php/jae

Email: editorinchief@aesonnigeria.org

adequately engaged. Thus, they have continued to rely on wild oil palm groves. Besides, the processing of fruits into oil and kernel is still being done by the traditional method, which is tedious and low yielding. However, oil palm industry is a source of livelihood to a large proportion of households in the rural areas of Southeast, Nigeria. But the level of engagement of rural households' in oil palm processing activities across the states in South East Nigeria is unknown. The study therefore comparatively analyzed of the level of engagement in palm oil processing among rural households in Southeast Nigeria. The study specifically identified the methods of processing oil palm produce, ascertained the level of household's engagement in palm oil processing, identified the constraints to palm oil processing in the study area.

\section{Methodology}

The South-East Agro-ecological Zone of Nigeria was the main focus of the study. The Zone lies between latitude $6^{\circ}$ and $9^{\circ} \mathrm{E}$ and $4^{\circ}$ and $7^{\circ} \mathrm{N}$ longitude, and has a total land mass of 952,400 hectares. The zone has a projected population estimate of 21,955,414 and is made up of five states viz: Abia, Anambra, Ebonyi, Enugu and Imo States (NPC, 2019). The population density is 173 persons per square kilometer (Umeh, 2018). About 60-70\% of the inhabitants engage in agriculture, mainly crop farming and animal rearing (Umeh, 2018). The study population comprised of all rural households who engage in oil palm fruit processing in South -East Nigeria. Multi-stage sampling procedure was used in the selection of the 540 respondents for the study. The $1^{\text {st }}$ stage involved the selection of three States (Abia, Anambra and Imo) from the zone using Simple Random Sampling (SRS) technique. The $2^{\text {nd }}$ stage involved the selection of 6 (six) Local Government Areas from the States selected using Simple Random Sampling (SRS). The LGAs selected were; Obingwa, Bende, Ikwuano, Isuikwuato, Ohafia and Ukwa East LGAs (Abia State), Ohaji Egbema, Owerre North, Ikeduru, Oguta, Obowo and Orlu EGAs (Imo State), and Aguata, Nnewi North, Orumba North, Idemili South, Oyi and Ihiala LGAs (Anambra State). This gave a total of 18 (eighteen) L.G.A.s. The $3^{\text {rd }}$ stage involved the use of Simple Random Sampling technique (SRS) in selecting 3 Communities each from the selected L.G.A.s bringing the total to 54 Communities. The $4^{\text {th }}$ and final stage involved the purposive selection of ten (10) palm oil processors each from the communities' selected. This is to ensure that only those who specialized in processing activities such as threshing or bunch quartering, fruit loosening, boiling of fruits, digestion of fruits, pressing/oil extraction, clarification and storage of product. A total of 540 (five hundred and forty) respondents constituted the sample size for the study. The study made use of primary data. Primary data were collected using structured questionnaire. Data for the study were analyzed using frequency, mean, gross margin model and ANOVA. To identify the methods of 
Creative Commons User License: CC BY-NC-ND

Abstracted by: EBSCOhost, Electronic Journals Service (EJS),

Google Scholar, Journal Seek, Scientific Commons,

Food and Agricultural Organization (FAO), CABI and Scopus

http://eoi.citefactor.org/10.11226/v25i3
Journal of Agricultural Extension

Vol. 25 (3) July, 2021

ISSN(e): 24086851; ISSN(Print); 1119944X

http://journal.aesonnigeria.org

http://www.ajol.info/index.php/jae

Email: editorinchief@aesonnigeria.org

processing oil palm fruits; this was measured using frequency and percentage on the different methods of processing oil palm produce. To ascertain the level of household's engagement in processing of oil palm fruit, this was measured using mean count. Engagement of respondents in processing was operationalized by using frequency or level of engagement. Extent of engagement was captured with 5point Likert type measurement scale of very high (5), high (4), moderate (3), low and very low. The constraints to engagement in production, processing and marketing of oil palm produce in the study area this was measured using frequencies and percentage. The hypothesis that there is no significant difference in level of household's engagement in processing of oil palm produce across the states in South East Nigeria was tested using ANOVA.

\section{Results and Discussion}

\section{Methods of Processing Oil Palm Produce}

Table 1 revealed that a fairly large proportion (58.1\%) of the respondents used semimodern/mechanized, about $21.5 \%$ processed oil palm using traditional method while $20.4 \%$ used modern method. Result from across the states equally showed that the majority (63.3\% in Imo, 56.7\% in Abia and $54.4 \%$ in Anambra) of the respondents used semi-modern method in the processing of their palm oil produce.

Table 1: Methods of palm oil processing

\begin{tabular}{lcccc}
\hline $\begin{array}{l}\text { Methods of oil palm } \\
\text { processing }\end{array}$ & $\begin{array}{c}\text { Abia } \\
(\mathbf{n = 1 8 0}) \\
\%\end{array}$ & $\begin{array}{c}\text { Anambra } \\
(\mathbf{n}=\mathbf{1 8 0}) \\
\%\end{array}$ & $\begin{array}{c}\text { Imo } \\
(\mathbf{n}=\mathbf{1 8 0}) \\
\%\end{array}$ & $\begin{array}{c}\text { Southeast } \\
(\mathbf{n}=\mathbf{5 4 0}) \\
\%\end{array}$ \\
\hline Traditional & 7.2 & 27.2 & 30.0 & 21.5 \\
Semi-modern/mechanized & 56.7 & 54.4 & 63.3 & 58.1 \\
Modern & 36.1 & 18.3 & 6.7 & 20.4 \\
\hline
\end{tabular}

\section{Source: Field Survey, 2020}

The result implied that the majority of the respondents used a combination of both traditional and modern method in the processing of their oil palm produce. The findings are in tandem with Osei-Amponsah et al., (2018) that small- scale production involves the use of traditional or semi-mechanized methods for oil extraction from the fresh fruit bunch. The result is plausible in that during processing, outdated equipment is mostly used among rural farmers in the study area. Ohimain and Angaye, (2016) posited that oil palm sector is dominated by smallholder 
Creative Commons User License: CC BY-NC-ND

Abstracted by: EBSCOhost, Electronic Journals Service (EJS),

Google Scholar, Journal Seek, Scientific Commons,

Food and Agricultural Organization (FAO), CABI and Scopus

http://eoi.citefactor.org/10.11226/v25i3
Journal of Agricultural Extension

Vol. 25 (3) July, 2021

ISSN(e): 24086851; ISSN(Print); 1119944X

http://journal.aesonnigeria.org

http://www.ajol.info/index.php/jae

Email: editorinchief@aesonnigeria.org

processors accounting for over $80 \%$ of Nigeria oil palm industry and using rudimentary equipment for processing. The reason for the predominant use of traditional and semi-modern methods of processing may be attributed to lack of finance to purchase the modern methods of processing, lack of technical knowhow on the use of the modern method, age, economic factors predominant in the rural area etc.

\section{Extent of Household's Engagement in Processing of Oil Palm}

Table 2shows a grand mean of 3.67 affirming that the respondents were highly engaged in the processing of oil palm produce. The results across the states equally showed that the level of engagement of rural households in oil palm processing in Imo state was high as affirmed with the grand mean of 4.03 while those in Anambra and Abia were moderately engaged with grand mean of 3.58 and 3.35 respectively.

Table 2: Level of household's engagement in processing

\begin{tabular}{lcccc}
\hline $\begin{array}{l}\text { Processing Stages of } \\
\text { oil palm produce }\end{array}$ & $\begin{array}{c}\text { Abia } \\
(\mathbf{n = 1 8 0})\end{array}$ & $\begin{array}{c}\text { Anambra } \\
(\mathbf{n = 1 8 0})\end{array}$ & $\begin{array}{l}\text { Imo } \\
(\mathbf{n = 1 8 0})\end{array}$ & $\begin{array}{l}\text { Southeast } \\
(\mathbf{n}=\mathbf{5 4 0 )}\end{array}$ \\
& $\bar{x}$ & $\bar{x}$ & $\bar{x}$ & Pooled $\bar{x}$ \\
\hline Threshing or bunch & 3.56 & 4.32 & 3.63 & 3.84 \\
quartering & & & & \\
Fruit loosening & 4.15 & 3.45 & 4.22 & 3.94 \\
Boiling of fruits & 4.41 & 3.64 & 4.32 & 4.12 \\
Fruit digestion & 2.47 & 3.00 & 4.35 & 3.27 \\
Pressing/oil extraction & 2.60 & 3.24 & 3.70 & 3.18 \\
Oil clarification & 2.54 & 3.49 & 3.52 & 3.18 \\
Packaging of oil & 3.55 & 3.85 & 4.07 & 3.82 \\
Storage & 3.48 & 3.62 & 4.46 & 3.85 \\
Grand mean & $\mathbf{3 . 3 5}$ & $\mathbf{3 . 5 8}$ & $\mathbf{4 . 0 3}$ & $\mathbf{3 . 6 7}$ \\
\hline
\end{tabular}

Source: Field Survey, 2020

The result implies that rural households in southeast Nigerian engage in the processing of oil palm produce as a profitable livelihood activity. It could be observed from the result that the processors were mostly engaged in boiling of fruits, fruit loosening, oil storage and threshing or bunch quartering. This may be attributed to the fact that some of the processors use local palm oil mills in their area in processing their palm fruit produce. Generally, the researchers observed that smallholder palm oil mills are found in several communities in Southeast Nigeria with few semi-mechanized and mechanized palm oil mills. Alabi et al. (2020) asserted that oil palm fruits postharvest activities were not only providing employment opportunities for the owners alone, but also serve as a means of employing others who could have been jobless, implies that these activities have entrepreneurial 
Creative Commons User License: CC BY-NC-ND

Abstracted by: EBSCOhost, Electronic Journals Service (EJS),

Google Scholar, Journal Seek, Scientific Commons,

Food and Agricultural Organization (FAO), CABI and Scopus
Journal of Agricultural Extension

Vol. 25 (3) July, 2021

ISSN(e): 24086851; ISSN(Print); 1119944X

http://journal.aesonnigeria.org

http://www.ajol.info/index.php/jae

Email: editorinchief@aesonnigeria.org

capabilities that could enhance the socio- economic status of rural households if well exploited. The active involvement of respondents observed in almost all the processing activities could be an indication that they were smallholder operators using manual labour for the majority of the activities. The finding is equally in agreement with Osei-Amponsah et al, (2018) assertion that majority of oil palm activities are done manually by rural household.

\section{Constraints to Engagement in Oil Palm Processing}

Table 4 shows that lack of modern processing equipment (86.5\%), instability of government policy $(80.0 \%)$, high cost of labour $(76.7 \%)$, lack of physical and social infrastructure $(71.5 \%)$, inadequate safety and healthy environments $(69.6 \%)$, lack of storage facility $(69.4 \%)$, lack of technical information (62.8\%), difficulty in obtaining credit facilities $(62.5 \%)$ and poor quality of products were the constraints to engagement in oil palm processing in the study area.

Table 4: Constraints to household engagement in processing of oil palm produce

\begin{tabular}{lcccc}
\hline Constraint to Processing of oil palm & $\begin{array}{c}\text { Abia } \\
(\mathbf{n = 1 8 0}) \\
\%\end{array}$ & $\begin{array}{c}\text { Anambra } \\
(\mathbf{n = 1 8 0}) \\
\%\end{array}$ & $\begin{array}{c}\text { Imo } \\
(\mathbf{n}=\mathbf{1 8 0}) \\
\%\end{array}$ & $\begin{array}{c}\text { Southeast } \\
(\mathbf{n}=\mathbf{5 4 0}) \\
\%\end{array}$ \\
\hline Lack of modern processing equipment & 95.0 & 84.4 & 80.0 & 86.5 \\
Instability of government policy & 88.9 & 67.8 & 83.3 & 80.0 \\
High cost of labour & 65.6 & 75.6 & 88.9 & 76.7 \\
Lack of infrastructure (eg, electricity) & 72.2 & 60.0 & 82.2 & 71.5 \\
Inadequate safety and healthy & 60.6 & 85.6 & 62.7 & 69.6 \\
environments & & & & \\
Lack of storage facilities & 51.1 & 89.4 & 67.8 & 69.4 \\
Lack of technical information & 56.1 & 52.2 & 80.0 & 62.8 \\
Difficulty in obtaining credit facilities & 61.1 & 54.4 & 71.7 & 62.5 \\
Poor quality of product & 71.8 & 57.2 & 55.0 & 61.7 \\
\hline
\end{tabular}

\section{Source: Field Survey, 2020}

${ }^{*}$ Multiple responses recorded

This result implies that the respondents encountered series of constraints in the processing oil palm produce in Southeast Nigeria especially in the areas of lack of modern processing equipment, instability of government policy and high cost of labour. Obviously, most rural communities in Nigeria lacks the basic social, physical and institutional infrastructural facilities. More so, due to high rate of rural-urban migration, labour is usually costly in the rural area. The findings therefore agreed with Alabi et al., (2020) who established that lack of funds, poor processing facilities and transportation problems constitute the major challenges facing oil palm industry in Nigeria. Ekenta, Ajala, Akinola and Oseni (2017) also asserted that palm fruit 
Creative Commons User License: CC BY-NC-ND

Abstracted by: EBSCOhost, Electronic Journals Service (EJS), Google Scholar, Journal Seek, Scientific Commons,

Food and Agricultural Organization (FAO), CABI and Scopus

http://eoi.citefactor.org/10.11226/v25i3
Journal of Agricultural Extension

Vol. 25 (3) July, 2021

ISSN(e): 24086851; ISSN(Print); 1119944X

http://journal.aesonnigeria.org

http://www.ajol.info/index.php/jae

Email: editorinchief@aesonnigeria.org

processing is still faced with a lot of problems including; inadequate finance, shortage of labour, scarcity of water and firewood and lack of effective processing techniques, irrespective of all the research efforts on improved palm oil processing methods over the years by research institutes.

\section{Difference in Level of Engagement of Rural Households in Processing of Oil Palm Produce}

Table 5 shows that there was a statistically significant difference in the level of engagement of rural households in processing of oil palm produce across the states in South East Nigeria at $5 \%$ level of probability.

Table 5: Difference in the level of engagement of rural households in processing of oil palm produce

\begin{tabular}{ll}
\hline States & Mean difference \\
\hline Abia & $3.3524^{\mathrm{b}}$ \\
Anambra & $3.5807^{\mathrm{b}}$ \\
Imo & $4.0314^{\mathrm{ab}}$ \\
LSD & 0.5580 \\
F- Test & $11.654^{\star \star \star}$ \\
Df & 537 \\
\hline
\end{tabular}

Source: Data computed from Field Survey, 2020.

F-value is significant at $P<0.05$

Key: means with the same letters were not significantly different

IThe result further revealed that there was a significant difference between the level of engagement of rural households in processing of oil palm produce in Imo state and Anambra and Abia. However, there was no significant difference in the level of engagement of rural households in processing of oil palm produce between Anambra and Abia States. The result implies that rural household in Imo were more engaged in palm oil processing than those of Anambra and Abia states in Southeast Nigeria. This may be attributed to the fact that there are several palm oil mills cited in the state which may have encouraged the rural households to engage in oil palm processing. This result is in tandem with Onu, et al (2021) that rural households in Imo state engaged in palm oil processing more than other states in Southeast Nigeria. The F-test value of 11.654 was statistically significant at $5 \%$ alpha level. Therefore, the null hypothesis which stated that there is no significant difference in level of household's engagement in processing of oil palm produce across the states in South East Nigeria was rejected at 5\% alpha level and concluded otherwise. 
Creative Commons User License: CC BY-NC-ND

Abstracted by: EBSCOhost, Electronic Journals Service (EJS),

Google Scholar, Journal Seek, Scientific Commons,

Food and Agricultural Organization (FAO), CABI and Scopus
Journal of Agricultural Extension

Vol. 25 (3) July, 2021

ISSN(e): 24086851; ISSN(Print); 1119944X

http://journal.aesonnigeria.org

http://www.ajol.info/index.php/jae

Email: editorinchief@aesonnigeria.org

\section{Conclusion and Recommendations}

The study comparatively analyzed the level of engagement in palm oil processing among rural households in Southeast Nigeria. Most of the processors used a combination of both traditional and modern method in the processing of their oil palm produce. The rural households in the study area highly engaged in the processing of oil palm produce as a profitable livelihood activity. The processors were mostly engaged in boiling of fruits, fruit loosening, oil storage and threshing or bunch quartering. The palm oil processors however encountered series of constraints in the processing oil palm produce in Southeast Nigeria especially in the areas of lack of modern processing equipment, instability of government policy and high cost of labour. The study therefore recommended that State and Federal Government should gear up efforts to provide basic infrastructure such as electricity and good, motorable roads in the oil palm belts so that the efficiency of processing oil palm products can be guaranteed. Enugu Electricity Distribution Company and other related government agencies should ensure constant electric supply in the rural area since light is a major constraint to oil palm processing. Rural electrification will reduce dependency on fuel wood, and thus stemming environmental degradation in the area.

\section{References}

Alabi, D. L., Famakinwa, M. \& Akinnawonu, O.E. (2020). Involvement of rural households in oil palm (Elaeis guineensis) fruits postharvest activities in Ondo State, Nigeria. Journal of Agricultural Extension, 24(1) Pp 42-53.

Ekenta, C.M., Ajala, M.K., Akinola, M.O. and Oseni, Y. (2017). Abandoned Nigerian economic resources: The case of oil palm. Int. J. Agric. Ext. Rural Dev. Studies, 4 (2), 1-16

Ekwe, K. C. (2019). Assessment of Subject Matter Specialists' Competencies in the activities On-farm Adaptive Research (OFAR) trials in Imo and Akwa Ibom States, Nigeria.

Eric, G. O.and Ikheloha, E. E. (2017). Analysis of the structure and performance of palm oil marketing in Edo State Nigeria. Global Approaches to Extension practice (GAEP), 3(1): 61-67.

Nwalieji, H.U. and Ojike, H.U. (2018). Characteristics of small-scale palm oil production enterprise in Anambra State. Journal of Agricultural Extension, 22(1): 22-34. 
Creative Commons User License: CC BY-NC-ND

Abstracted by: EBSCOhost, Electronic Journals Service (EJS), Google Scholar, Journal Seek, Scientific Commons,

Food and Agricultural Organization (FAO), CABI and Scopus

http://eoi.citefactor.org/10.11226/v25i3
Journal of Agricultural Extension

Vol. 25 (3) July, 2021

ISSN(e): 24086851; ISSN(Print); 1119944X

http://journal.aesonnigeria.org

http://www.ajol.info/index.php/jae

Email: editorinchief@aesonnigeria.org

Ohimain, E. I. and Angaye, E. I. (2016). Contribution of manual energy to palm oil processing by smallholders in Nigeria. Sky Journal of Agricultural Research, 3(1), $137-141$.

Onu S. E., Ekwe K. C. and Nwachukwu I. M (2021) Gender Analysis of Rural Households' Involvement in Oil Palm Production, Processing and Marketing in Southeast Nigeria. Journal of Community \& Communication Research 6(1) Pp.76-84

Osei-Amponsah, C., Agbotse, P., Swanzy, F. and Stomph, T. J. (2018). Role of smallscale enterprises in Agricultural Development Agendas: Insights from oil palm processing enterprises in the Kwaebibirem district of Ghana. Ghana Journal of Agric. Sci., 52(1), Pp131-144.

Oyeronke, A. T. and Adedotun, Y. O. (2019). Socio-economic factors affecting the choice of oil palm fruit processing technologies in Ondo State, Nigeria. Invited paper presented at the 6th African Conference of Agricultural Economists, September 23-26, 2019, Abuja, Nigeria. Number of pages

Partnership Initiatives in The Niger Delta (PIND) Foundation. (2019). Palm oil value chain project. Available online at https://pindfoundation.org/project/palm-oilvalue-chainproject/

Udoh, O. S. and Essien, B. S. (2018). Palm oil processing and marketing and sustainable livelihood in rural communities of Akwa Ibom State, South-South- Nigeria. Journal of Business and Management (IOSR-JBM), 17(10): 43-50.

Ukwuteno, S. E. Eboh E.I and J. Ocheja, (2018). Determination of costs and returns of oil palm production in Kogi State, Nigeria, International Journal of Research in Agriculture and Forestry, 5(1), 27-33.

Umeh C. I (2018). Evaluation of participation of rural youths in agricultural/rural development programmes in South-east Nigeria. A Ph.D dissertation presented to the Department of Rural Sociology and Extension. MOUAU.

Statista (2020) Estimate of palm oil production in Nigeria. Annual report published by Simon Verella. www.statista.com 